Fenner, J. 1991. Late Pliocene-Quaternary quantitative diatom stratigraphy in the Atlantic sector of the Southern Ocean. Proceedings. Ocean Drilling Program. Scientific Results, 114, 97-121.

Flohn, H. 1965. Warum ist die Sahara trocken? Z. Meteorol., 17, 316320 .

Flohn, H. and S. Nicholson. 1980. Climatic fluctuations in the arid belt of the "Old World" since the last glacial maximum: possible causes and future implications. Palaeoecol. Afr., 12, 3-12.

Gersonde, R. and L. H. Burckle. 1990. Neogene diatom biostratigraphy of ODP Leg 113, Weddell Sea (Antarctic Ocean). Ocean Drilling Program. Proceedings. Scientific Results, 113, 761-769.

Harwood, D. M. 1986. Diatom biostratigraphy and palececology with a Cenozoic history of Antarctic ice sheets. (Ph.D. dissertation, Ohio State University.)

Harwood, D. M. and T. Maruyama. 1992. Middle Eocene to Pleistocene diatom biostratigraphy of Southern Ocean sediments from the Kerguelen Plateau, Leg 120. Ocean Drilling Program. Proceedings. Scientific Results, 120, 683-734.

Harwood, D. M., R.P. Scherer and P.-N. Webb. 1989. Multiple Miocene marine productivity events in West Antarctica as recorded in Upper Miocene sediments beneath the Ross Ice Shelf (Site J-9). Marine Micropalaeontology, 15(1-2), 91-115.

Hodell, D. A. 1993. Late Pleistocene paleoceanography of the South Atlantic sector of the Southern Ocean: Ocean Drilling Program hole 704A. Paleoceanography, 8, 47-69.

Howard, W.R. and W.L. Prell. 1992. Late Quaternary surface circulation of the southern Indian Ocean and its relationship to orbital variations. Paleoceanography, 7(1), 79-117.

Karl, H. A., E. Reimnitz and B.D. Edwards. 1987. Extent and nature of Ross Sea unconformity in the western Ross Sea, Antarctica. In Cooper, A. K. and F.J. Davey, eds. The Antarctic continental margin: geology and geophysics of the western Ross Sea. Houston, TX, CircumPacific Council for Energy and Mineral Resources, 77-92. (Earth Science Series 5B.)

Kellogg, T. and R.S. Truesdale. 1979. Late Quaternary paleoecology and paleoclimatology of the Ross Sea: the diatom record. Marine Micropalaeontology, 4, 37-158.

Kukla, G. 1989. Long continental records of climate - an introduction. Palaeogeogr. Palaeoclimatol. Palaeoecol., 72, 1-9.

MacAyeal, D. R. 1992. Irregular oscillations of the West Antarctic ice sheet. Nature, 359(6390), 29-32.

McCollum, D. W. 1975. Diatom stratigraphy of the Southern Ocean. Deep Sea Drilling Project. Initial Reports, 28, 515-571.

Mercer, J.H. 1978. West Antarctic ice sheet and $\mathrm{CO}_{2}$ greenhouse effect: a threat of disaster. Nature, 271(5643), 321-325.

Savage, M. L. and P.F. Ciesielski. 1983. A revised history of glacial sedimentation in the Ross Sea region. In Oliver, R. L., P. R. James and J. B. Jago, eds. Antarctic earth science. Cambridge, etc., Cambridge University Press, 555-559.

Scherer, R. P. 1991. Quaternary and Tertiary microfossils from beneath Ice Stream B: evidence for a dynamic West Antarctic ice sheet history. Palaeogeogr. Palaeoclimatol. Palaeoecol., 90(4), 359-412.

Scherer, R. P. 1992. Diatom paleoproductivity and sediment transport in West Antarctic basins and the Neogene history of the West Antarctic ice sheet. (Ph.D. dissertation, Ohio State University.)

Schrader, H. -J. 1976. Cenozoic planktonic diatom biostratigraphy of the Southern Pacific Ocean. Deep Sea Drilling Project. Initial Reports, 35, 605-671.

Spencer-Cervato, C. and 7 others. 1992. Study of diachroneity of Neogene plankton and revised biostratigraphy. In Sarnthein, M., J. Thiede and R. Zahn, eds. Fourth International Conference on Paleoceanography. Short- and Long-Term Global Change: Records and Modelling, 21-25 September 1992, Kiel/Germany. Kiel, GEOMAR/Christian-AlbrechtsUniversität. Geologisch-Paläontologisches Institut und Museum, 268. (GEOMAR Report 15/Reports Geologisch-Paläontologisches Institut 57.)

Webb, P.-N. and D. M. Harwood. 1991. Late Cenozoic glacial history of the Ross embayment, Antarctica. Quat. Sci. Rev., 10(2-3), 215-223.

Wornhardt, W. W. and P. R. Vail. 1991. Revision of the Plio-Pleistocene cycles and their application to sequence stratigraphy and shelf and slope sediments in the Gulf of Mexico. Transactions of the Gulf Coast Association of Geological Societies, 41, 719-744.

The accuracy of references in the text and in this list is the responsibility of the author, to whom queries should be addressed.
SIR,

\section{Bering Glacier surge and iceberg-calving mechanism at Vitus Lake, Alaska, U.S.A.}

Bering Glacier, the largest in North America with an area, including tributaries, of about $5200 \mathrm{~km}^{2}$ (Molnia, 1993) (Fig. 1a), was observed during photographic flights on 19 and 24 June 1993 during a field program near the terminus. Extensive fresh crevassing throughout regions that were unperturbed in air photographs taken on 16 March 1993 by R. Krimmel indicated an acceleration of flow characteristic of surge initiation. Historically, the surge cycle for Bering Glacier has been approximately 20 years. The last major surge occurred in 1965-67. A minor surge, similar in extent to the preliminary surge evidence described here, occurred in 1981 but did not propagate into the piedmont lobe.

Figure $1 \mathrm{a}$ is a full-resolution synthetic-aperture radar (SAR) image of Bering Glacier, acquired on 13 September 1992 by the European Remote Sensing satellite (ERS-1). The nominal resolution is $30 \mathrm{~m}$. The terminus is at the lower left. Vitus Lake - which has been greatly enlarged by up to $10 \mathrm{~km}$ of retreat since the 1965 67 surge (Molnia, 1993) - is between the terminus and the coast, which appears along the bottom of the image. Figure lb shows the flight path of 19 June and the approximate locations of the photographs in Figures 2-8. The flight of 24 June continued to upper Bagley Icefield, which did not show evidence of participating in the surge at that time.

Figure 2 shows a heavily crevassed bulge of ice at the west end of Grindle Hills; the rectangular seracs result from increasing transverse extension superimposed on longitudinal extension. Figure 3, a relatively short distance up-glacier, shows fresh crevassing in the foreground and right middle distance, indicating propagation of the surge down the distributary which flows around the north and east sides of Grindle Hills (Fig. lb). The transient late-June snow line also appears in the middle distance. The intersecting crevasses illustrate the effect of orthogonal tensile principal stress components. Figure 4 shows fresh intersecting crevasses farther up-glacier, above the transient late-June snow line, indicating a complex surface stress field. Figure 5 shows a broad surge front with fresh rectangular seracs near Khitrov Hills. The distance along the crest, transverse to the flow direction (lower left to upper right) is on the order of $2 \mathrm{~km}$. In Figure 6, which is a close-up of the surge front shown in Figure 5, a small lake is visible at bottom center. The open "holes" or fractures visible through the lake suggest subglacial water pressure locally in excess of the ice-overburden pressure at the surge front. However, the lake was clear blue rather than muddy as might be expected if it had formed as a result of direct upwelling from the bed. The vertical distance from the lake to the crest of the surge front is probably on the order of $100 \mathrm{~m}$. Figure 7 shows a small lake in mid-glacier. The open crevasses clearly visible beneath the lake are probably on the order of $10-20 \mathrm{~m}$ apart.

The striking crevasse patterns shown in these air 

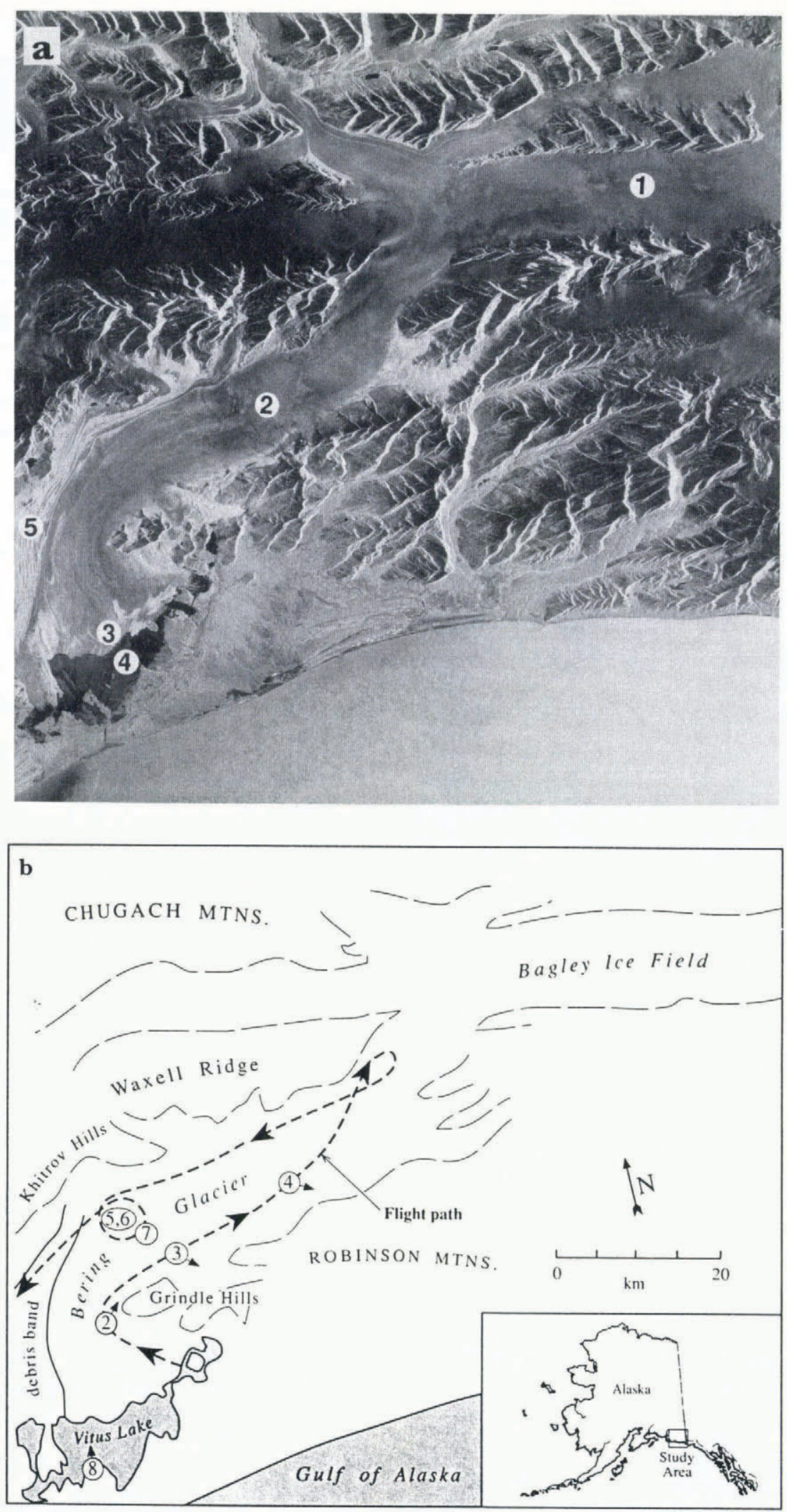

Fig. 1. a. Satellite synthetic-aperture radar image of Bering Glacier and Bagley Icefield, south-central Alaska, acquired by ERS-1 on 13 September 1992 (orbit 6085, ID 32934100, full resolution). The numbers indicate (1) Bagley Icefield, (2) Bering Glacier, (3) the calving ice front, (4) Vitus Lake and (5) band of rock debris between Bering Glacier and Steller Glacier tributary (not shown). (Copyright ESA 1992.) b. Sketch map corresponding to Figure 1a. Dashed line is the route of 19 June 1993 flight. Circled numbers correspond to approximate locations of photographs in Figures 2-8. Arrows indicate camera-look directions. Photographic flight of 24 June 1993 continued to upper Bagley Icefield, which did not show evidence of surging at that time.

photographs did not extend across the entire Bering Glacier. They are relatively local. However, accelerating ice movement may also have been occurring in the relatively uncrevassed regions where chaotic surface fracturing did not occur because of thicker ice and a smoother bed. New crevassing faded out about $7 \mathrm{~km}$ 


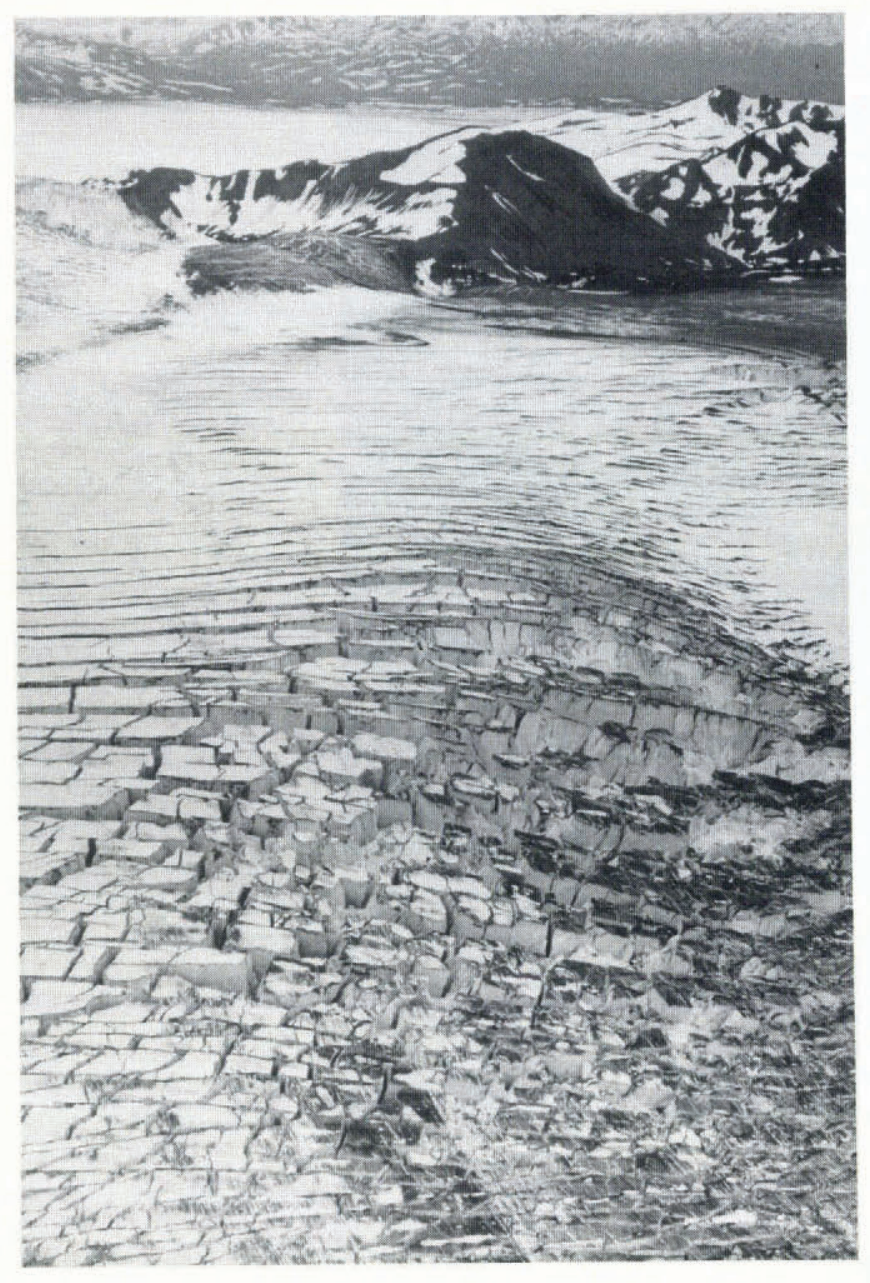

Fig. 2. Heavily crevassed bulge of surging ice near the west end of Grindle Hills, with rectangular seracs caused by increasing transverse tensile strain superimposed on high longitudinal tensile-strain rates. (Air photographs in Figures 2-7 by C. Lingle.)

down-glacier from the eastern end of Waxell Ridge (aircraft turn-around loop in Figure 1b) where Bering Glacier descends from Bagley Icefield, suggesting that in

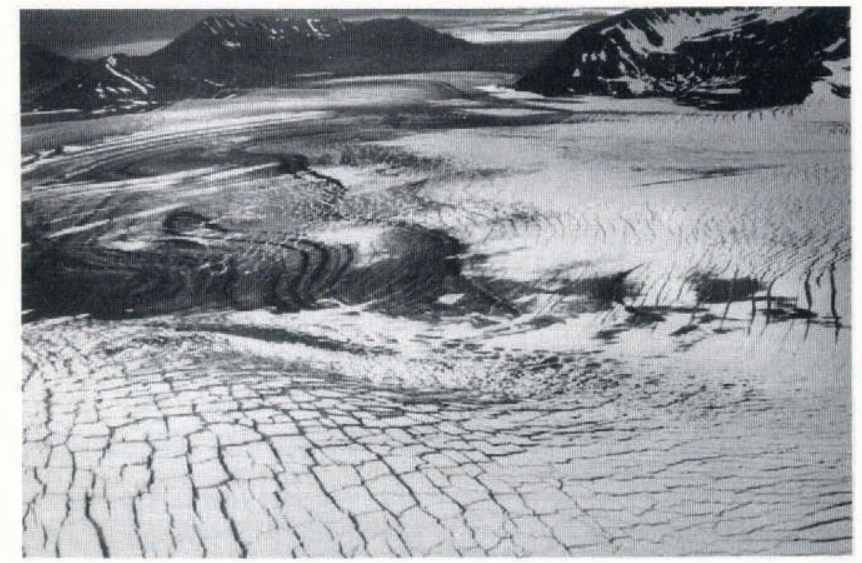

Fig. 3. Fresh crevassing farther up-glacier from Figure 2, showing that the surge is propagating down the distributary (ice moving towards center background) which flows around the northern and eastern sides of Grindle Hills (right background). The crevasses in the foreground show the effect of orthogonal tensile principal stresses.

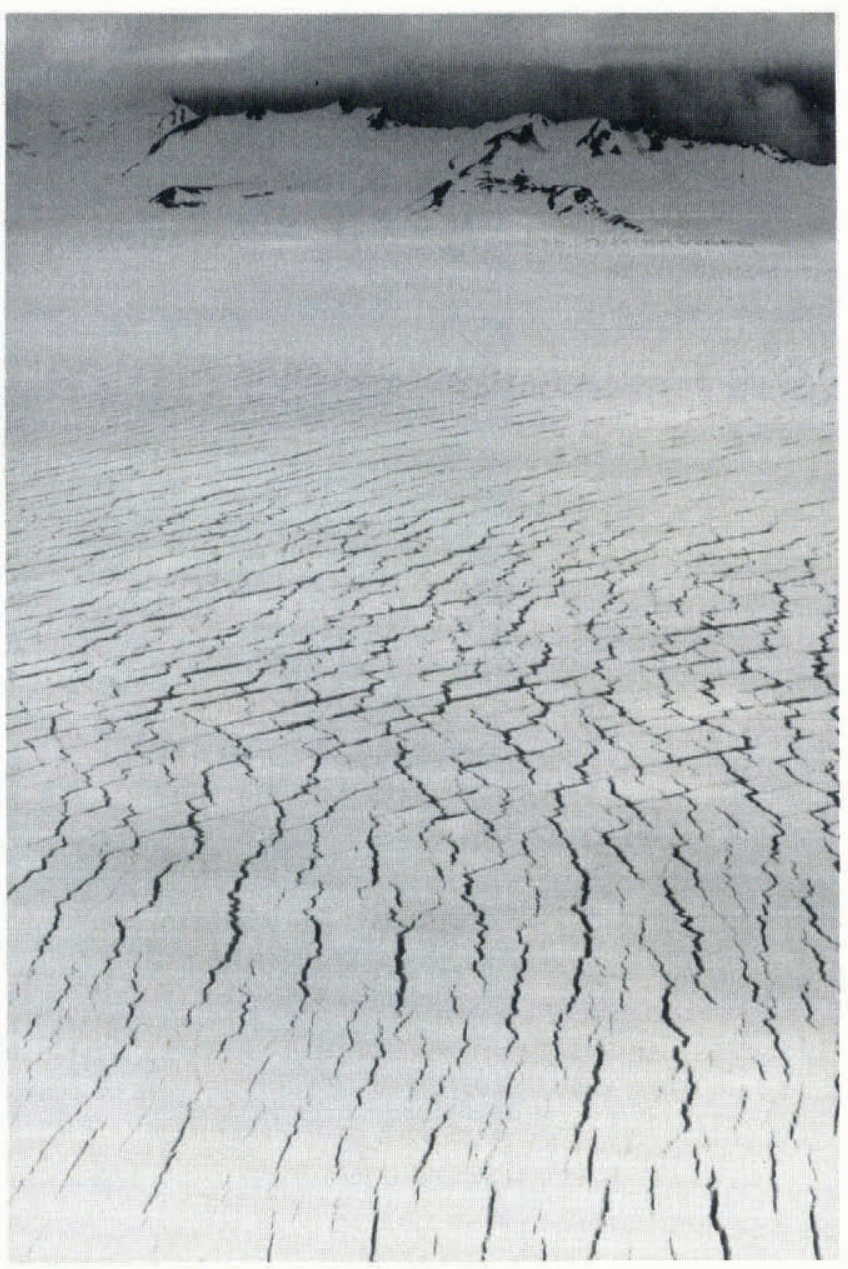

Fig. 4. Fresh intersecting crevasses above the transient lateJune snow line, indicating a complex surface-stress regime.

late June the surge was just beginning to propagate into the upper icefield that forms the bulk of the accumulation area. The surge had also just started to propagate into the

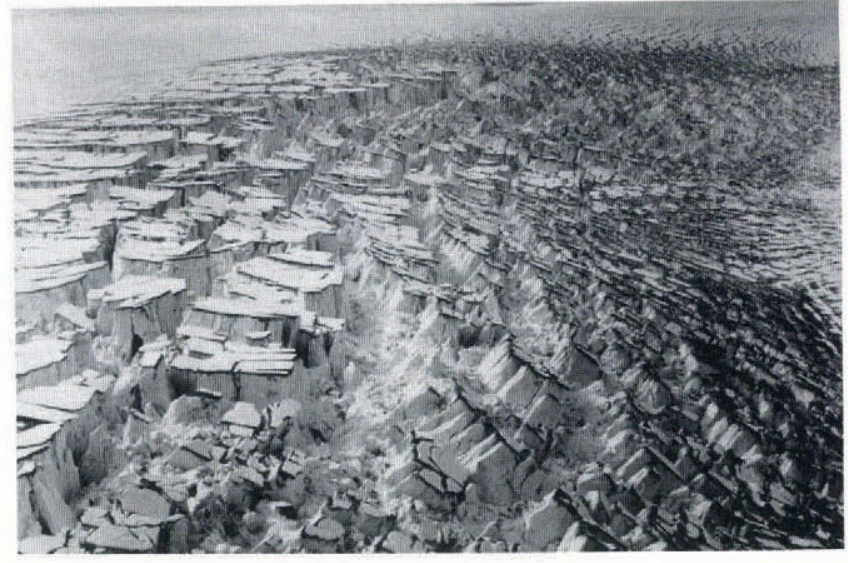

Fig. 5. Broad bulge of surging ice shattered into rectangular seracs near Khitrov Hills. Distance along crest of bulge is on the order of $2 \mathrm{~km}$. 


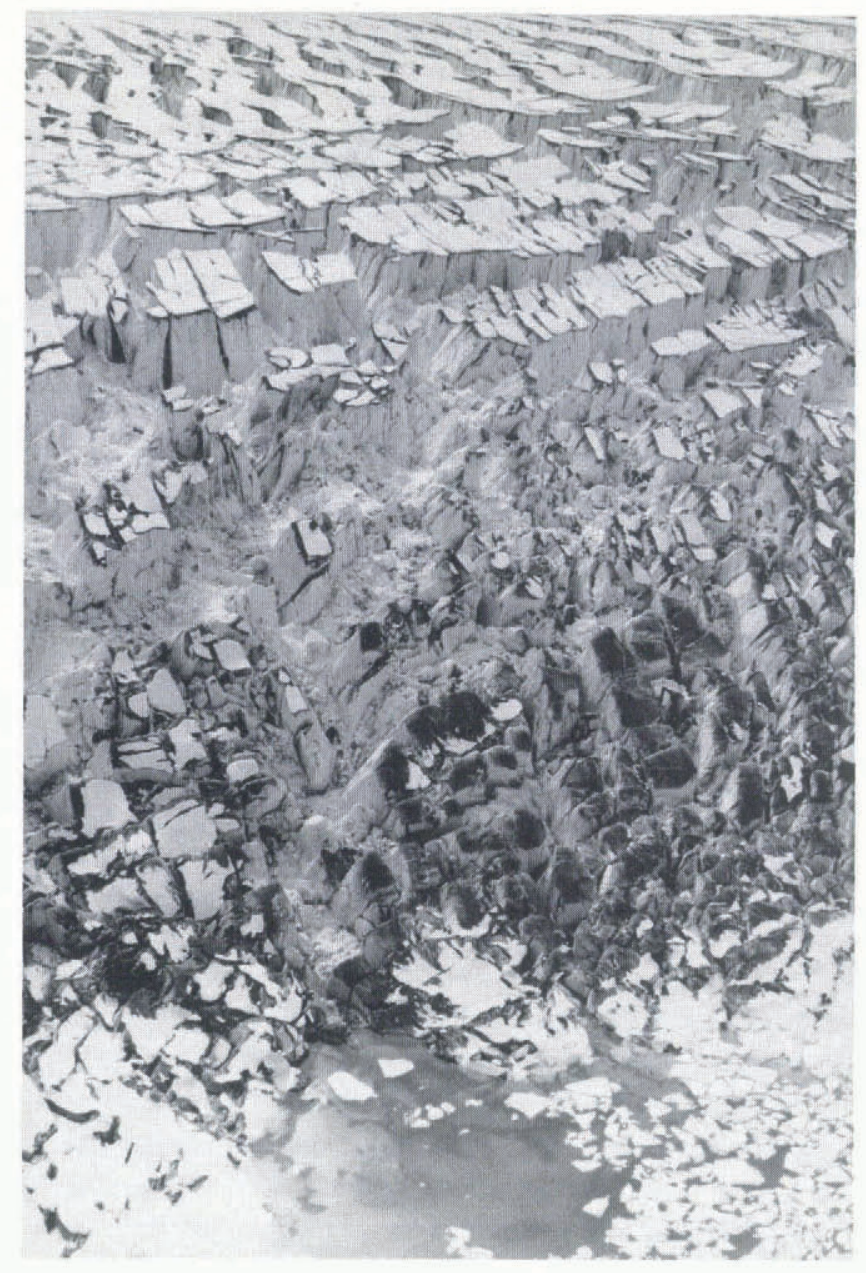

Fig. 6. Close-up of the surge-front shown in Figure 5. Note the small lake over fractured ice at the bottom center, suggesting subglacial water pressure in excess of the iceoverburden pressure at the leading edge of the bulge. However, the lake is clear blue (not muddy). Vertical distance from lake to crest of bulge is on the order of $100 \mathrm{~m}$.

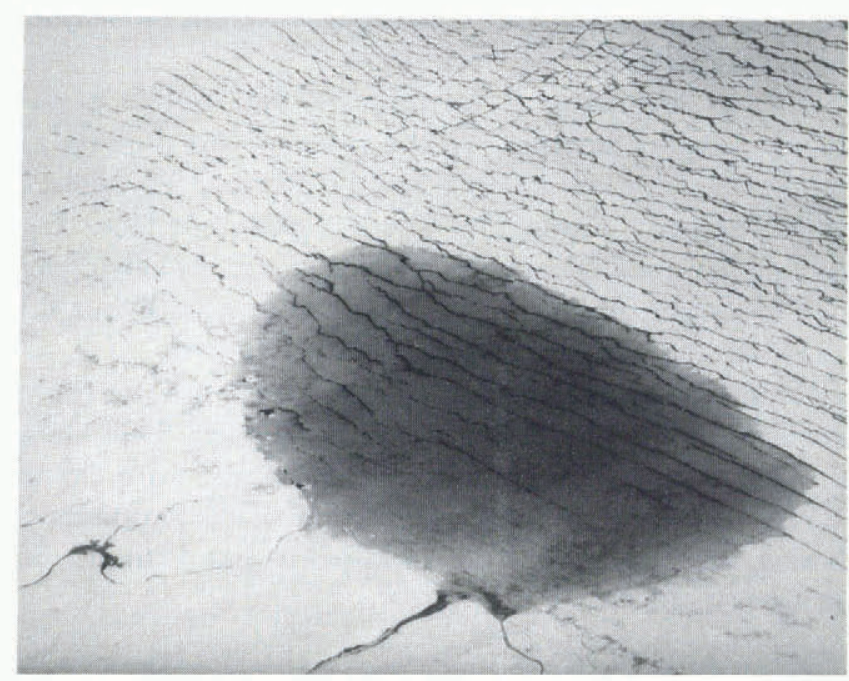

Fig. 7. Small lake overlying open crevasses in broad central area of Bering Glacier, suggesting that the subglacial water pressure may be locally in excess of the iceoverburden pressure. "Reverse flow" through the moulin at the near edge may be the source of the water. The lake is clear blue (not muddy). Crevasses beneath the lake are probably about 10-20 m apart. large piedmont lobe near the terminus.

In North America, surge-type glaciers exist only in the high, heavily glacierized ranges of south-central Alaska and the Yukon Territory, where 204 were identified by Post (1969) from air photography. Relatively few, however, have been observed surging. Only oneVariegated Glacier, near Yakutat Bay in south-central Alaska - has been measured in detail throughout an entire surge cycle (Kamb and others, 1985). Numerous questions thus remain regarding this important problem in glacier mechanics for ice masses that are much larger in size, such as Bering Glacier, or located in different climatic regimes (Clarke, 1987; Raymond, 1987). For example, the Variegated Glacier surge started, surprisingly at that time, in January 1982. The ice velocity dropped precipitously in late June and the surge seemed to have stopped by mid-August (Kamb and others, 1985). However, the surge began again in October 1982, then came to a final halt in mid-July 1983 (Kamb and others, 1985). The question of whether glacial surges in general are characterized by similar seasonal timing is of interest. Although available evidence suggests that the present surge of Bering Glacier started in the spring, the airphotographic coverage of 16 March 1993 does not extend far enough up-glacier to rule out midwinter initiation. The timing and exact location of surge onset thus remain ambiguous.

The question of whether surges characteristically originate in accumulation areas and propagate downglacier into ablation areas is also of interest. In the case of Variegated Glacier, the surge originated near the head and was confined to the upper glacier during the first winter (Kamb and others, 1985). In the case of Bering Glacier, the present surge seems to have originated well below the equilibrium line. Rapid and continuing propagation both down-glacier into the piedmont lobe and up-glacier into Bagley Icefield was observed by B. Molnia, A. Post, D. Trabant and colleagues during July 1993.

The first observed surge of Bering Glacier was in 1837 (Pierce and Winslow, 1979), although it was not recognized as such. Indirect evidence, consisting of subsequent air photography by B. Washburn and dated trees, indicates that surges occurred in about 1920 and 1940. Another surge, well-documented with air photography by A. Post, occurred in 1957-60. Bering Glacier surged again only 5 years later, in 1965-67, an unexpected event also documented with air photography by A. Post. Conceivably, the latter may have been a second pulse of the 1957-60 surge. As noted above, Variegated Glacier surged in two pulses during two successive winters (Kamb and others, 1985). The 1965-67 Bering Glacier surge was followed by 28 years of quiescence (interrupted by the 1981 event), accompanied by almost complete stagnation of the piedmont lobe near the terminus.

Regularly spaced loops in a medial moraine parallel to Waxell Ridge and Khitrov Hills (up-glacier from the "debris band" in Figure la and b), spaced at intervals comparable to the ice displacement during the 1957-60 surge (up to $9 \mathrm{~km}$ ), indicate earlier surging of the Bering Glacier main trunk past steady-flow tributaries with a period of about 20 years (Post, 1972). Descriptions of the Holocene history, recent surge history and recent retreat 
behaviour of Bering Glacier have been given by Muller and others (paper in preparation) and Molnia and others (paper in preparation); see also Bush (1991).

\section{Calving mechanism}

Bering Glacier is a tide-water glacier, in the sense that it is grounded well below sea level in its lower reaches (Meier and Post, 1987; Molnia, 1993), in addition to being a surge-type glacier. Calving occurs, however, not into a salt-water fjord or the ocean but rather into Vitus Lake. Figure 8 shows that the calving terminus is a low ice cliff; in some areas, the ice surface slopes down very nearly to lake level. Icebergs that have calved float substantially higher than the general elevation of the terminus, demonstrating that the terminus is held below the level of hydrostatic equilibrium. This differs considerably from the high, active ice cliff at the calving front of Columbia Glacier prior to the onset of drastic retreat, and during drastic retreat since 1984 (e.g. Meier and others, 1985).

This calving mechanism appears to be a consequence of small to negligible forward velocities and velocity gradients along the ice front, caused by stagnation of the Bering piedmont lobe following the 1965-67 surge. "Normal" calving is evidently inhibited by the attendent absence of deformation. Ablation is therefore the dominant process. The ice surface, which was substantially higher after the two-fold surge of 1957-60 and 1965-67, is steadily lowered towards lake level (Fig. 9a). As ablation lowers the surface below the level of hydrostatic equilibrium, the terminus is "held down" by the tensile strength of the ice, which resists the upward bending moment imposed by unbalanced hydrostatic pressure acting on the bottom surface (Fig. 9b). This bending moment increases as ablation continues to lower the top surface. Fracture occurs, presumably, at the point of maximum moment (at the distance from the ice front where the surface rises above the level of hydrostatic equilibrium), or alternatively, where an irregularity on the bottom surface results in local stress concentration

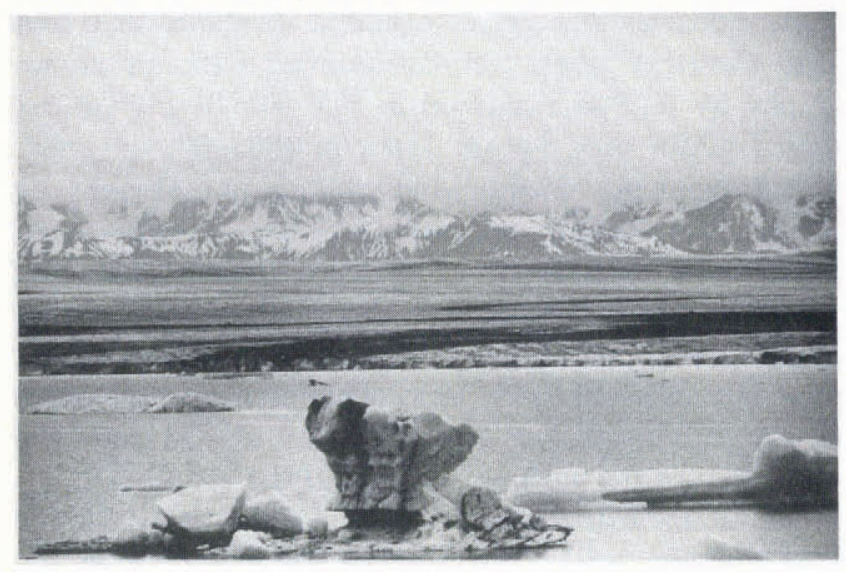

Fig. 8. Calving front with low ice cliff and broad, relatively stagnant piedmont lobe of Bering Glacier viewed across Vitus Lake (200 $\mathrm{mm}$ telephoto lens). Example of "pop-up" iceberg is in the foreground. Many icebergs were observed in Vitus Lake floating higher than the general elevation of the terminus. (Photograph by C. Lingle.)

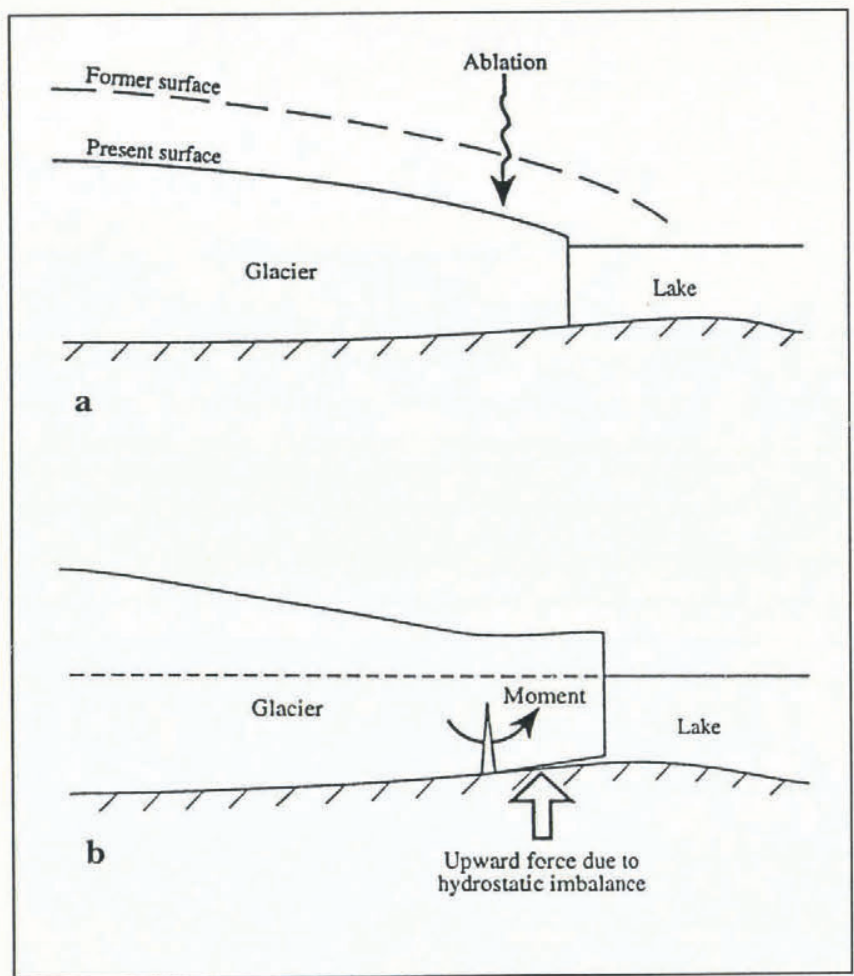

Fig. 9. Ablation-driven calving at Vitus Lake. a. Ablation lowers the surface of the piedmont lobe, where "normal" calving is inhibited by low deformation rates at stagnant ice front. b. Fracture is caused by upward-bending moment induced when the surface is lowered below hydrostatic equilibrium. The resulting icebergs float higher than the elevation of the terminus.

(Fig. 9b). The resulting iceberg "pops up" and floats higher than the elevation of the terminus (see example in the foreground of Figure 8). This mechanism is, in effect, the reverse of the calving mechanisms described by Reeh (1968) for floating outlet glaciers and Hughes (1992) for grounded ice walls, in that the bending moment imposed by hydrostatic imbalance causes fracture from the bottom up rather than from the top down.

It can reasonably be anticipated that retreat of the Bering Glacier terminus will be reversed and the calving mechanism described above will be dramatically altered when the surge propagates into the piedmont lobe. The calving front may then become a high, actively calving ice cliff. Whether the present surge will be as extensive as the 1957-60 and 1965-67 surges is not yet known.

Note added in proof: Vertical aerial photographs acquired by R. Krimmel on 10 September 1993 show propagation of the surge to the terminus, with up to $1.5 \mathrm{~km}$ of advance on the western side of the terminus of Bering Glacier, near the rock-debris band shown in Figure 1b.

\section{Acknowledgements}

Support for photographic flights in conjunction with space-borne synthetic-aperture radar studies of glaciers in Alaska and the Yukon Territory was provided by NASA's Polar Research Program, grant NAGW-2827 to C. Lingle and W. Harrison, and by NASA grant NAGW-2746 to 
U. Herzfeld. Support for field work in the area of the Bering Glacier terminus was provided by the U.S. Geological Survey. We thank G. Streveler, G. Wiles, K. Hale and P. Green for collaboration and assistance with the field program, W. Harrison for useful discussions and S. Ranney for air support.

Geophysical Institute,

University of Alaska,

CRAig S. Lingle

Fairbanks, Alaska 99775-0800, U.S.A.

U.S. Geological Survey (Ret.), 10275 SW 127th Street,

Vashon, Washington 98070, U.S.A.

Scripps Institution of Oceanography,

University of California San Diego,

La Folla, California 92093-0205, U.S.A.

U.S. Geological Survey,

BRUGE F. MOLNIA

National Center, Mail Stop 917,

Reston, Virginia 22092, U.S.A.

U.S. Geological Survey,

Ice and Climate Project,

University of Puget Sound,

Tacoma, Washington 98416, U.S.A.

Geophysical Institute and

Dept. of Geology and Geophysics,

University of Alaska,

Fairbanks, Alaska 99775-0800, U.S.A.

\section{August 1993}

\section{REFERENCES}

Bush, S. 1991. Bering Glacier may be in retreat. Eos, 72(43), 466-467.

Clarke, G.K.C. 1987. Fast glacier flow: ice streams, surging, and tidewater glaciers. J. Geophys. Res., 92(B9), 8835-8841.

Hughes, T. 1992. Theoretical calving rates from glaciers along ice walls grounded in water of variable depths. J. Glaciol., 38(129), 282-294.

Kamb, B. and 7 others. 1985. Glacier surge mechanism: 1982-1983 surge of Variegated Glacier, Alaska. Science, 227(4686), 469-479.

Meier, M. F. and A. Post. 1987. Fast tidewater glaciers. J. Geophys. Res., 92(B9), 9051-9058.

Meier, M. F., L. A. Rasmussen and D. S. Miller. 1985. Columbia Glacier in 1984: disintegration under way. U.S. Geol. Surv. Open-File Rep. 8581.

Molnia, B. 1993. Major surge of the Bering Glacier. Eos, 74(29), 321322.

Pierce, R. A. and J.H. Winslow, eds. 1979. H.M.S. Sulphur on the northwest and California coasts, 1837 and 1839; the accounts of Captain Edward Belcher and Midshipman Francis Guillemard Simpkinson. Kingston, Ontario, The Limestone Press.

Post, A. 1969. Distribution of surging glaciers in western North America. 7. Glaciol., 8(53), 229-240.

Post, A. 1972. Periodic surge origin of folded medial moraines on Bering piedmont glacier, Alaska. F. Glaciol., 11(62), 219-226.

* Present address: Institute of Arctic and Alpine Research, University of Colorado, Boulder, Colorado 80309-0450, U.S.A.
Raymond, C. F. 1987. How do glaciers surge? A review. J. Geophys. Res., 92(B9), 9121-9134.

Reeh, N. 1968. On the calving of ice from floating glaciers and ice shelves. 7. Glaciol., 7(50), 215-232.

The accuracy of references in the text and in this list is the responsibility of the authors, to whom queries should be addressed. 